Newfoundland and Labrador Studies

Megan Gail Coles. Small Game Hunting at the Local Coward Gun Club

\title{
Alexandra Trnka
}

Volume 36, numéro 1, 2021

URI : https://id.erudit.org/iderudit/1082219ar

DOI : https://doi.org/10.7202/1082219ar

Aller au sommaire du numéro

Éditeur(s)

Faculty of Arts, Memorial University

ISSN

1719-1726 (imprimé)

1715-1430 (numérique)

Découvrir la revue

Citer ce compte rendu

Trnka, A. (2021). Compte rendu de [Megan Gail Coles. Small Game Hunting at the Local Coward Gun Club]. Newfoundland and Labrador Studies, 36(1),

141-144. https://doi.org/10.7202/1082219ar d'utilisation que vous pouvez consulter en ligne.

https://apropos.erudit.org/fr/usagers/politique-dutilisation/ 
Megan Gail Coles. Small Game Hunting at the Local Coward Gun Club. Toronto: House of Anansi Press, 2019. ISBN 978-1-48700-171-1

"It is not right to selectively see only certain people in focus" (275), Megan Gail Coles tells us in the third quarter of Small Game Hunting at the Local Coward Gun Club, before a sexual assault occurs that the reader has been made to see coming. The scene is a flashback, a return to a traumatic event that happened weeks before the novel's temporal present, which unfolds over the course of a single day.

The phrase is a fitting thesis for Coles's debut novel, in which she alternates between the perspectives of seven different characters brought together by a location: The Hazel. The Hazel is a faux downhome cottage restaurant that serves as a meeting point for characters who come from vastly different socio-economic backgrounds. Through her multiple shifting perspectives, Coles places the reader in the uncomfortable position of occupying the minds of difficult characters, characters who are either being exploited and abused due to their marginalized social positions, or, in turn, the perspectives of their abusers.

Iris and Olive are the novel's most vulnerable characters, two women who have both moved to St. John's from the Great Northern Peninsula and are palpably struggling to cope with the poverty and misogyny that ensnares them. Coles uses these characters to illustrate the systemic racism against the Indigenous population of Newfoundland that exists on the island and the way in which rural Newfoundlanders' are plagued by classist stereotyping and discrimination. Through their entanglements with the novel's male characters, Coles explores the dynamics of consent, coersion, and manipulation in conventional but toxic romantic and sexual relationships as well as in more explicit experiences of rape and sexual assault. In this exploration, Coles delves into the minds of perpetrators and the desperate and harmful beliefs they harbour in order to justify their behaviour and consider themselves good, moral people, justifications that range from "he had not forced her, she had kissed him back" (333) to "asking people if they thought you could rape a hooker" (290). By writing these situations 
side by side, Coles creates a stunningly nuanced and realistic depiction of rape culture's far reach and crushing repercussions.

Coles does not pretend to start her novel at any kind of beginning; rather, she thrusts us into a complex and evolving web of relationships, already rife with tension, and impels us to navigate its connections. The reader must play catch-up in order to understand the narrative links between characters through a series of flashbacks that exceed the limited temporal frame of the novel. The heartbreak of Coles's novel sets in when these relationships come into focus to devastating effect, when the reader begins to understand that the ways in which characters are connected reveal underlying patterns of abuse, manipulation, and profound personal failure.

The shape of the plot does not easily disclose itself, as Coles's narrator gives generous space to her characters' inner thoughts and observations, in a stream-of-consciousness style narration that luxuriates in tangential ideas and memories that, when collected, reveal intimate portraits of each character. Coles experiments with this stream-ofconsciousness style, often penning somewhat unruly paragraphs that then crystallize into concise phrases that distill the melancholy of the novel with striking depth. When Damian reflects on doing drugs into the early morning with a group of acquaintances, and the fragmented, chaotic conversations that happen in these spaces, Coles adopts the frenzied tone of the scene in her writing:

Yes, of course, telling tall tales is an island tradition. They made a commercial about it. They've made a commercial about every jesus thing now. Wipe your nose, b'y. Wipe your arse, b'y. You got a little something something. But come on. Come off it. Come down. Calm. Down. Sure. One more time, one more time, I'm listening now and again, one more time at maximum volume before your nose bleeds and/or the cops show up. Don't be like that. You might as well go to bed out of it if you're going to be like that. I won't remember tomorrow but tell me again 
and again and again why it is important we ravage ourselves like this. (78).

The narrator's style is a balancing act. At times winding and at others remarkably concise, Coles makes certain that though the relationships she describes are complex and nuanced, we do not misunderstand her message: "Damian drank because Damian's people drink" (76), she tells us. The narrator does not feign objectivity in these moments. She is as much a character in her novel as the others, an eighth person with her own thoughts and judgments and the capacity to dip in and out of the other characters' minds. She is diffuse, omnipotent, and yet focused and opinionated. She breaks the fourth wall to assure that the reader does not miss important details: "No one hates John more than John hates John. Clock that, it's vital" (343). She addresses us directly to guide our reading, ensuring we understand that John's wrongdoings stem in part from this self-hatred.

Small Game Hunting at the Local Coward Gun Club is a social analysis of Newfoundland, a survey of the varieties of people that the province produces and the unique brand of misogyny and racism that festers as a result of the island's vices, intergenerational addiction and class disparity among others. "In St. John's," Coles tells us, "being not shitty is the same as being awesome" (199). She does not couch her social commentary with ambiguity or refrain from candidly stating her point: "Why is the rural Newfoundlander [insert anything here]? The answer is poverty. Why is the rural Newfoundlander [insert anything here]? Still poverty. Why is the rural Newfoundlander [insert anything here]? POVERTY. POVERTY. POVERTY. FUCK!” (206). The narrator's frustration and disappointment is undeniable, and these emotional expressions only underscore the urgency of Coles's project. This urgent repetition is the novel's ethos, as Coles piles tragedy upon tragedy such that it is impossible for the reader to emerge from her world unburdened, to continue reproducing the harm of selectively seeing only certain people in focus. The novel is an unflinching denunciation of this compartmentalization and an insistence on directly 
acknowledging the ubiquity of rape culture and the many ways in which it is visible in our communities.

The accumulating trauma is so relentless that Coles convinces us that to finish with a happy ending would be unrealistic. At the novel's end, the reader is left on a precipice. After being hit by a car, Iris lays on the street in the slush; it is unclear, by the last page, whether help will arrive in time. Leaving the ending open, dangling in this critical moment, Coles forces us to anticipate what happens next for ourselves, and decide how dismal we believe the world to be.

Alexandra Trnka

Montreal 